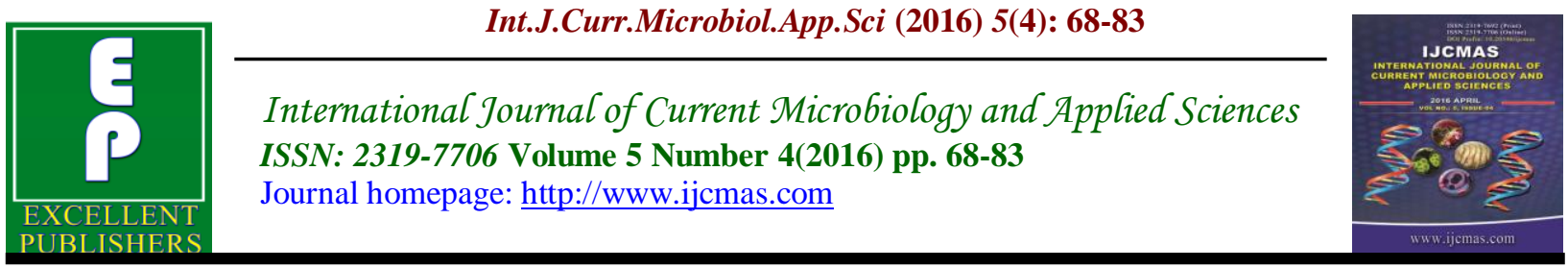

Original Research Article

http://dx.doi.org/10.20546/ijcmas.2016.504.011

\title{
Detection of Rotavirus A and Escherichia coli from Diarrhea Cases in Children and Coliphage Characterization
}

\author{
Marwa M. Yaqoob ${ }^{1}$, Kuther H. Mahdi ${ }^{1}$, Hayder Abdulhussein Al-Hmudi ${ }^{1}$ * \\ and Mariem N. Mohammed-Ali ${ }^{2}$ \\ ${ }^{1}$ College of Science, University of Basra, Basra, Iraq \\ ${ }^{2}$ College of Medicine, University of Basra, Basra, Iraq \\ *Corresponding author
}

\begin{tabular}{|c|c|}
\hline & A B S T R A C T \\
\hline & $\begin{array}{l}\text { Acute gastroenteritis is a common disorder in young children. The purpose of this } \\
\text { study was to comprehensive determination of main diarrheagenic pathotypes in } \\
\text { children with acute gastroenteritis in the pediatric population in Basra city/Iraq, and } \\
\text { characterization of E.coli phag. This study determined Rotavirus A and bacterial } \\
\text { pathogens in } 300 \text { stool samples of children by using different techniques. In our } \\
\text { study among children with gastroenteritis was } 93 / 300(31 \%) \text { Rotavirus positive }\end{array}$ \\
\hline Keywords & $\begin{array}{l}\text { cases by Immunochromatographic (IC) test as monoinfection, coinfection, and } \\
\text { mixing infections. Out of } 50 \text { IC positives fecal samples were tested using EM, }\end{array}$ \\
\hline $\begin{array}{l}\text { Acute } \\
\text { gastroenteritis, }\end{array}$ & $\begin{array}{l}50(100 \%) \text { were found positive. A total of } 80 \text { stools were examined for Rotavirus } \\
\text { using polyacrylamide gel electrophoresis. The overall agreement was } 68 / 80(85 \%) \text {. }\end{array}$ \\
\hline $\begin{array}{l}\text { Rotavirus, } \\
\text { Escherichia coli, }\end{array}$ & $\begin{array}{l}\text { Out of } 277 / 300(92.33 \%) \text { bacterial pathogens isolated, } 163(54.33 \%) \text { children had } \\
\text { infections with EPEC Escherichia coli. } 39 / 300(13 \%) \text { cases with Salmonella spp. }\end{array}$ \\
\hline Coliphage. & While, Shigella spp. was reported in $12 / 300(4.01 \%)$ samples. Also parasitic causes \\
\hline Artic & $\begin{array}{l}\text { were found in } 6 / 300(2 \%) \text { samples. Coinfection with another pathogen was } \\
\text { observed in } 109 / 300(36.34 \%) \text { cases, coinfection with Rotavirus and EPEC }\end{array}$ \\
\hline $\begin{array}{l}\text { Accepted: } \\
\text { 08 March } 2016 \\
\text { Available Online: } \\
10 \text { April } 2016\end{array}$ & $\begin{array}{l}\text { Escherichia coli were the most common and occurred in } 75 / 300(25 \%) \text {. The phage } \\
\phi E C-\mathrm{MH} 1 \text { was isolation successfully from sewage. The phage titer was determined } \\
\text { by serial dilution }\left(10^{-1}, 10^{-2}, 10^{-3}, 10^{-4}, 10^{-5}, 10^{-6}, 10^{-7}, 10^{-8}, 10^{-9}\right) \text { of the sample by } \\
\text { counting the number of plaque forming units (p.f.u.) for each dilution. Our } \\
\text { results revealed that dilution factor } 10^{-2} \text { was the best countable number of plaques. }\end{array}$ \\
\hline & $\begin{array}{l}\text { Effects of chloroform on phage titer during different times was completely } \\
\text { inactivated, while sensitivity to saline environments was } 3.0^{*} 10^{-4}, 4.2^{*} 10^{-4}, 4.2 * 10^{-} \\
4,5.6^{*} 10^{-4}, 6.0^{*} 10^{-4}, 6.7 * 10^{-4}, 8.2^{*} 10^{-4}, 8.0^{*} 10^{-4} \text {, and } 8.4^{*} 10^{-4} \text { during } 5,10,15,20 \text {, } \\
25,30,35 \text { and } 40 \text { minutes. The statistical analysis was significantly decrease } \mathrm{P} \leq \\
0.05 \text { in phage titer at the temperature } 50 \mathrm{C}^{\circ} \text { and } 65 \mathrm{C}^{\circ} \text { comparing with phage } \\
\text { titer at the temperature } 37 \mathrm{C}^{\circ} \text {. We concluded that Rotavirus A could be } \\
\text { diagnosed in stool samples of children with gastroenteritis by IC test as a } \\
\text { rapid technique. Rotavirus and EPEC Escherichia coli were the most common } \\
\text { coinfectious agents responsible for gastroenteritis. }\end{array}$ \\
\hline
\end{tabular}




\section{Introduction}

Fecal pollution of water resources is a problem of increasing worldwide concern (Sauer, 2000). Acute gastroenteritis is a common disorder in young children, and the associated dehydration is a leading cause of admission to hospital in industrialized countries and a major source of mortality in developing countries (Parkin et al., 2009). Acute nonbacterial gastroenteritis is one of the most important infectious diseases that severely affects infants and young children (Liu et al., 2010). Group A rotavirus is a major pathogen of severe gastroenteritis in infants and young children worldwide (Parashar et al., 2006). The virus is transmitted through the fecal-oral route. There are seven species of this virus referred to as A,B,C.D,E,F and G with Rotavirus A being the most common species also identified as a major cause of dehydrating gastroenteritis in infants and young children (Armah et al., 2003). Rotaviruses belong to the family Reoviridae. The genome of rotavirus consists of 11 double helix molecules of RNA containing 18,555 base pairs. Each helix is a gene, numbered 1 to 11 by decreasing size. Each gene codes for one protein, except genes 9 and 11 codes for two. The RNA is surrounded by a threelayered icosahedral protein capsid. Viral particles are up to $76.5 \mathrm{~nm}$ in diameter and are not enveloped (Surendran, 2008). Each year, worldwide, rotavirus causes approximately 111 million episodes of gastroenteritis, 25 million that result in clinic visits and 2 million hospitalizations. Children in the poorest countries accounting for $82 \%$ of rotavirus deaths (Parashar et al., 2003). Traditionally, electron microscopy has been used to screen stool samples taken from suspected viral gastroenteritis patients (Atmar and Estes, 2001). Enteropathogenic Escherichia coli (EPEC) are a major cause of diarrhea amongst infants in developing countries (Gomes et al., 1991; Mangia et al., 1993). Escherichia coli were first isolated by Theodor Escherich in 1885 as Bacterium coli commune, which was isolated from the feces of healthy newborns (Berg, 2004). Bacteriophages are the most abundant entities on earth. These bacterial viruses have genetic material in the form of either DNA or RNA, encapsidated by a protein coat (Clark and March, 2006). Phages infect bacteria and can propagate in two possible ways; lytic life cycle and lysogenic life cycle. When phages multiply vegetatively they kill their hosts and the life cycle is referred to as lytic life cycle. On the other hand some phages known as temperate phages can grow vegetatively and can integrate their genome into host chromosome replicating with the host for many generations (Inal, 2003). For this global issue on public health, we undertook this study in order to find out the distribution of main diarrheagenic pathotypes; Rotavirus A and E.coli among hospitalized children with diarrhea in Basra city/Iraq, and determination of coinfections between these pathotypes. Also the first aim was to develop easily performable detection method for Rotavirus A infections, furthermore, characterization of E.coli phag.

\section{Materials and Methods}

Stool samples were collected between $15 / 11 / 2014$ and $1 / 4 / 2015$ from children 0 to 59 months of age who were hospitalized in Basra hospital for women and children, Basra/Iraq. A total of 300 children with acute gastroenteritis were enrolled, including 199 males and 101 females. The stool samples were collected in sterilized plastic container, transported under ice and stored at - $20 \mathrm{C}$ till further processing. Approximately 10\% (Wt/vol) suspension of stool specimens was prepared with distilled sterile water or phosphate - buffered saline 
(PBS) and clarified by centrifugation at $2000 \mathrm{~g}$ for 10 minutes twice (Kageyama et al., 2003). Data on the clinical manifestations, such as age, gender and monthly distribution were analyzed.

\section{General Stool Examination (GSE)}

Stool specimens of the children were subjected to direct examination for Entamoeba histolytica, Giardia lamblia and other cysts or ova of parasites.

\section{Detection of Rotavirus A}

The samples were checked for group A Rotavirus by Immunochromatographic (IC) test, direct electron microscopy (EM) and polyacrylamide gel electrophoresis (PAGE).

\section{Detection of Rotavirus by IC Test (one Step Rotavirus Test Device)}

The one step rotavirus test device (Acon, Germany) is a rapid chromatographic immunoassay for the qualitative detection of rotavirus in human feces specimens to aid in the diagnosis of rotavirus infection. This test was performed according to the manufacturer's instructions.

\section{Direct Electron Microscope (EM)}

A 50 rotavirus-positive samples by IC test were confirmed by electron microscope (Zeiss supra 55vp, Germany) according to Bishop, et al., 1974 with some modifications. About $10 \%$ of stool count was suspended PBS. Fecal suspension was clarified at $2000 \mathrm{~g}$ for $10 \mathrm{~min}$ twice.For negative staining, after staining by $3 \%$ phosphotungistic acid, a drop of about $10 \mu \mathrm{l}$ of the virus suspension to be studied was applied to surface of a Petri dish, after drying, the grid was immediately coated with it.

\section{Polyacrylamide Gel Electrophoresis (PAGE)}

PAGE was carried out on the faecal suspensions for 80 Rotaviruses positive by IC using a standard method which includes extraction of RNA genome according to the

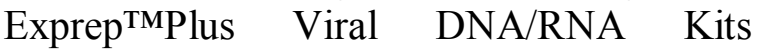
(Bioneer, Korea) by using automated extraction (Automated Nucleic Acid Extraction System, Bioneer, Korea) according to the manufacturer's instructions. The RNA was subsequently electrophoresed in $10 \%$ acrylamide gels for $6-8 \mathrm{~h}$. at $100 \mathrm{~V}$ at room temperature and segments were visualized by Ethidium bromide staining according to the method of Herring et al., 1982 with some modifications.

\section{Isolation and Identification of Bacterial Species}

Standard microbiology laboratory techniques were used to isolate and identify Escherichia coli, Shigella sp. and Salmonella sp. from stool samples in MacConkey agar (Salucea, The Netherland) and X.L.D agar (LabM Limited, UK) as previously described (Forbes et al., 1998; Collee et al., 1996; Gupta, 1995). The identification of bacterial pathogens was later confirmed by routine bacteriological, biochemical assays and api 20 Enterobacteraceae system. Escherichia coli were tested for antimicrobial susceptibility onto Muller-Hinton agar (Salucea,The Netherland) according Baur et al. (1966) by the standard disk diffusion method, using commercially prepared antibiotic disks containing Impenien (IMP), Trimethoprim (TMP), Ampicillin (AM), Ceftriaxone (CRO) and Doxycyclin (DO). Accordingly, the size of inhibition zone determines whether isolated bacteria were resistant, intermediate, or sensitive. 


\section{Bacteriophage Isolation and Purification}

A $200 \mathrm{ml}$ sewage samples for phage isolation were obtained from Al-Sadar hospital in Basra/Iraq according to Sambrook et al. 2001. The host range of phages was determined by the spot test. The phage titer was determined by serial dilution $\left(10^{-1}, 10^{-2}, 10^{-3}, 10^{-4}, 10^{-5}, 10^{-6}, 10^{-7}, 10^{-8}, 10^{-}\right.$ ${ }^{9}$ ) of the sample and then plated $0.1 \mathrm{ml}$ each of the dilution and the E.coli culture onto NA plates. The plates were incubated overnight at $37^{\circ} \mathrm{C}$ and examined for the presence of plaques. The phage titer was determined by counting the number of plaque forming units (p.f.u.) for each dilution. At this stage choosing dilution factor in which gave the best countable number of plaques for using in further experiments including temperature, chloroform and saline sensitivity.

\section{Statistical Analysis}

Analysis of the data obtained was made by using SSPS software. Data of the present study was analyzed by chi square test, $\mathrm{P}$ values $\leq 0.05$ were considered statistically significant. Calculation of mean values and standard deviation (SD) were made for some clinical manifestations.

\section{Results and Discussion}

\section{Characterization of Study Population}

The characteristics of the children whose stool samples showed positive results for Rotavirus and bacterial pathogens were summarized in Table 1 and 2. Age of the 300 recruited children ranged from 0 to 59 month (mean \pm standard deviation: $11.02 \pm 12.3$ months) and their male/female ratio was 199(66.33\%):101(33.67\%). So present study showed the males were more susceptible to the infection with significantly elevated value $(\mathrm{P}<0.001)$ than females. Boys are twice as likely as girls to be admitted to hospital (Rheingans et al., 2006). Males are more frequently affected than females (Broor and Singh, 1984). The age period between $(0-5)$ and $(6-11)$ month was significantly prone (34\% and $36 \%$, respectively) to the infection $(\mathrm{P}<0.001)$. In contrast, the age period (24-59) month was significantly decreased $(7.34 \%)$ to the infection (Table, 1). Almost every child has been infected with rotavirus by age five (Parashar et al., 2006). Because at this age feeding starts and child put things in his mouth. Rotavirus affects $95 \%$ of all children by the age of 5 years. Infection rates for rotavirus are highest in the under 5-year old age group and decrease progressively towards adulthood as immunity acquired in childhood protects most adults(Parashar et al.1998). Regarding clinical manifestations, all diarrheagenic pathotypes (Table, 2) were complained with diarrhea 300/300(100\%), Vomiting 129/300(43\%), dehydration $8 / 300(2.67 \%)$ and fever $247 / 300(82.34 \%)$ with highly significant differences $(\mathrm{P}<$ 0.001). Symptoms include a profuse watery diarrhea, vomiting, abdominal pain and possibly fever and severe cases may lead to death, mainly through acute dehydration (Diggle, 2007). Within study population, during 15/11/2014 and 1/4/2015, present study shows diarrheal children cases in all months and become increased in December $96 / 300$ (32\%), January 60/300 (20\%), March 56/300 (18.67\%), February 50/300 (16.66\%) and November 38/300 (12.67\%) with significant differences ( $\mathrm{P} \leq 0.05)$. Rotavirus infections rates vary seasonally with the majority of cases in temperate climates occurring in the winter months between November and February (Gleizes $e t$ al., 2006). In tropical and developing countries this seasonality is less marked, and infection occur year-round (Parashar et al., 1998). Overall, diarrheagenic pathotype 
cases become increased from December to January.

\section{Rotavirus Detection}

\section{IC Test}

With an increasing number of reports on Rotavirus and an estimated increase in the number of patients of Rotavirus infection, the demand for rapid diagnosis of this infectious disease is dramatically expanding. IC has been developed as a rapid diagnostic test, ELISA although it still takes more than 4 hours to obtain the results. In this study, a simple, easy-to-read, and rapid detection test for Rotavirus using an IC membrane strip was developed. This method took a shorter time; approximately 30 minutes to complete the assay with limited equipment needed such as centrifuge machines and micropipettes. Based on the results in the current study by IC test, rotaviruses were detected in 93/300 (31\%) samples (Figure, 1; Table, 1).

Immunochromatographic test is one of the representative methods in rapid diagnosis, and it is widely used to detect various infectious diseases, such as influenza virus, rotavirus, and adenovirus (Fujimoto et al., 2004; Hara, 2002, Tsutsumi et al., 1999, Bon et al., 2007, Hara et al., 2006). The IC can theoretically detect $1 / 100$ to $1 / 10$ of the viral load found in clinical samples, which is almost equivalent to the detection power of electron microscopy (Atmar and Estes, 2001). Therefore it may be justified to use IC for screening the stool samples.

\section{PAGE}

Electron microscopy and polyacrylamide gel electrophoresis are also used to determine the virus (Beards, 1988). Basic evaluation was performed by comparison of the results of IC with those obtained by EM and on the results of PAGE.A photograph of electrophoresis for samples shown in Figure 2. A total of 80 stools were examined for Rotavirus using polyacrylamide gel electrophoresis. The overall agreement was $68 / 80(85 \%)$ with no significant differences. The occurrence of rotavirus-positive samples that yielded negative results by PAGE was possibly due to an insufficient RNA concentration. The rotavirus RNA segments which are different in size are separated by polyacrylamide gel electrophoresis and are observed as RNA pattern after staining of the RNA in gel. The RNA patterns are distinct among different rotavirus species and also different strains (Kobayashi et al., 2007). Studies on the electrophoretic migration patterns of viral genomic dsRNA segments (electropherotyping) have allowed the classification of rotaviruses into two major groups, the long (L) and the short (S) electropherotypes (Kapikian et al., 2001).

\section{Direct EM}

IC test for group A rotavirus could be used as an alternative rapid detection method, then were confirmed by electron microscopy. A total of 50 IC positives fecal samples were tested using EM. A 50(100\%) were found positive and showed the characteristic morphology of rotavirus of wheel- like appearance of rotavirus particles (Figure, 3). Rotavirus is shed in high concentration in the stool $\left(\sim 10^{12}\right.$ viruses/g) of children with gastroenteritis (Surendran, 2008), and thus can be easily identified on electron microscopy of stool samples which is one of the most specific tests for diagnosis. The method is also useful in evaluating the sensitivity and specificity of commercial virus detection kits (Curry et al., 2006). 
Table.1 The Age Distribution of Study Population

\begin{tabular}{|c|c|c|c|c|c|}
\hline \multirow[b]{2}{*}{ Pathotypes /300 } & \multicolumn{5}{|c|}{ Age/ month } \\
\hline & $0-5$ & 6-11 & 12-17 & $18-23$ & 24-59 \\
\hline \multicolumn{6}{|c|}{ Monoinfections } \\
\hline Rotavirus & 4 & 1 & 0 & 0 & 0 \\
\hline Escherichia coli & 61 & 55 & 28 & 9 & 10 \\
\hline Salmonella spp. & 4 & 0 & 0 & 2 & 0 \\
\hline Shigella spp. & 2 & 0 & 0 & 0 & 0 \\
\hline Entamoeba histolytica & 0 & 0 & 1 & 0 & 2 \\
\hline Giardia lamblia & 0 & 1 & 0 & 2 & 0 \\
\hline Total & 71 & 57 & 29 & 13 & 12 \\
\hline \multicolumn{6}{|c|}{ Coinfections } \\
\hline Rotavirus + E. coli & 27 & 30 & 6 & 8 & 4 \\
\hline Rotavirus + Salmonella spp. & 0 & 2 & 0 & 0 & 0 \\
\hline Rotavirus + Shigella spp. & 0 & 1 & 1 & 0 & 0 \\
\hline E. coli $i+$ Salmonella spp. & 0 & 11 & 4 & 3 & 5 \\
\hline E. coli + Shigella spp. & 0 & 3 & 2 & 1 & 1 \\
\hline Total & 27 & 47 & 13 & 12 & 10 \\
\hline \multicolumn{6}{|c|}{ Mixing infections } \\
\hline Rotavirus + E. coli + Salmonella spp. & 4 & 3 & 1 & 0 & 0 \\
\hline Rotavirus + E. coli + Shigella spp. & 0 & 1 & 0 & 0 & 0 \\
\hline Total & 4 & 4 & 1 & 0 & 0 \\
\hline Final total (\%) & $102(34 \%)$ & $108(36 \%)$ & $43(14.33 \%)$ & $25(8.33 \%)$ & $22(7.34 \%)$ \\
\hline
\end{tabular}

Table.2 Clinical Information of Positive Cases

\begin{tabular}{|c|c|c|c|c|}
\hline \multirow[b]{2}{*}{ Pathotypes /300 } & \multicolumn{4}{|c|}{ Sign and symptom } \\
\hline & Diarrhea & Vomiting & Dehydration & Fever \\
\hline \multicolumn{5}{|c|}{ Monoinfections } \\
\hline Rotavirus & 5 & 5 & 0 & 1 \\
\hline Escherichia coli & 163 & 27 & 2 & 151 \\
\hline Salmonella spp. & 6 & 1 & 0 & 6 \\
\hline Shigella spp. & 2 & 1 & 0 & 2 \\
\hline Entamoeba histolytica & 3 & 3 & 0 & 3 \\
\hline Giardia lamblia & 3 & 3 & 0 & 3 \\
\hline Total & 182 & 40 & 2 & 166 \\
\hline \multicolumn{5}{|c|}{ Coinfections } \\
\hline Rotavirus + E. coli & 75 & 68 & 0 & 47 \\
\hline Rotavirus + Salmonella spp. & 2 & 1 & 0 & 1 \\
\hline Rotavirus + Shigella spp. & 2 & 1 & 0 & 0 \\
\hline E. coli $i+$ Salmonella spp. & 23 & 5 & 1 & 19 \\
\hline E. coli + Shigella spp. & 7 & 7 & 4 & 7 \\
\hline Total & 109 & 82 & 5 & 74 \\
\hline \multicolumn{5}{|c|}{ Mixing infections } \\
\hline Rotavirus + E. coli + Salmonella spp. & 8 & 7 & 1 & 6 \\
\hline Rotavirus + E. coli + Shigella spp. & 1 & 0 & 0 & 1 \\
\hline Total & 9 & 7 & 1 & 7 \\
\hline Final total $(\%)$ & $300(100 \%)$ & $129(43 \%)$ & $8(2.67 \%)$ & $247(82.34 \%)$ \\
\hline
\end{tabular}


Table.3 Monoinfections, Coinfections and Mixing Infections of Positive Cases

\begin{tabular}{|c|c|c|c|}
\hline Pathotypes /300 & Monoinfections & Coinfections & Mixing infections \\
\hline Rotavirus & $5(1.66 \%)$ & \multirow{4}{*}{$\begin{array}{c}\text { Rotavirus }+ \text { E. coli } \\
75(25 \%) \\
\text { Rotavirus }+ \text { Salmonella spp. } \\
2(0.67 \%) \\
\text { Rotavirus }+ \text { Shigella spp. } \\
2(0.67 \%) \\
\text { E. coli } i+\text { Salmonella spp. } \\
23(7.67 \%) \\
\text { E. coli }+ \text { Shigella spp. } \\
7(2.33 \%) \\
\end{array}$} & \multirow{4}{*}{$\begin{array}{l}\text { Rotavirus }+ \text { E. coli }+ \\
\text { Salmonella spp. } \\
8(2.66 \%) \\
\text { Rotavirus }+ \text { E. coli }+ \\
\text { Shigella spp. } \\
1(0.34 \%)\end{array}$} \\
\hline Escherichia coli & $163(54.33 \%)$ & & \\
\hline Salmonella spp. & $6(2 \%)$ & & \\
\hline Shigella spp. & $2(0.67 \%)$ & & \\
\hline Entamoeba histolytica & $3(1 \%)$ & & \\
\hline Giardia lamblia & $3(1 \%)$ & & \\
\hline Total & $182(60.66 \%)$ & $109(36.34 \%)$ & $9(3 \%)$ \\
\hline
\end{tabular}

Table.4 Antibiotic Susceptibility Test

\begin{tabular}{|c|c|c|}
\hline Antibiotic & R \% & S\% \\
\hline Impenien (IMP) & $\mathbf{0}$ & $\mathbf{1 0 0}$ \\
\hline Trimethoprim (TMP) & $\mathbf{1 0 0}$ & $\mathbf{0}$ \\
\hline Ampicillin (AM) & $\mathbf{1 0 0}$ & $\mathbf{0}$ \\
\hline Ceftriaxone (CRO) & $\mathbf{7 6 . 6 6}$ & $\mathbf{2 3 . 3 4}$ \\
\hline Doxycyclin (DO) & $\mathbf{1 0 0}$ & $\mathbf{0}$ \\
\hline
\end{tabular}

Table.5 Determination of Phage Titer

\begin{tabular}{|c|c|c|c|c|c|c|}
\hline Plate & $\begin{array}{c}\text { Volume of } \\
\text { Phage }\end{array}$ & Dilution & $\begin{array}{c}\text { Dilution } \\
\text { factor (DF) }\end{array}$ & $\begin{array}{l}\text { Plague } \\
\text { Per }\end{array}$ & \multicolumn{2}{|c|}{$\begin{array}{c}\text { Titer }=\text { Plague } * D F \backslash \text { Volume } \\
\text { of Phage Plated }(\mathrm{ml})\end{array}$} \\
\hline 1 & 0.1 & $10^{-1}$ & $10^{-1}$ & 80 & $80 * 10^{1} / 0.1$ & $800 * 10^{1}$ \\
\hline 2 & 0.1 & $10^{-1}$ & $10^{-2}$ & 85 & $85 * 10^{2} / 0.1$ & $850 * 10^{2}$ \\
\hline 3 & 0.1 & $10^{-1}$ & $10^{-3}$ & 76 & $76^{*} 10^{3} / 0.1$ & $760 * 10^{3}$ \\
\hline 4 & 0.1 & $10^{-1}$ & $10^{-4}$ & 56 & $56 * 10^{4} / 0.1$ & $560 * 10^{4}$ \\
\hline 5 & 0.1 & $10^{-1}$ & $10^{-5}$ & 32 & $32 * 10^{5} / 0.1$ & $320 * 10^{5}$ \\
\hline 6 & 0.1 & $10^{-1}$ & $10^{-6}$ & 27 & $27 * 10^{6} / 0.1$ & $270 * 10^{6}$ \\
\hline 7 & 0.1 & $10^{-1}$ & $10^{-7}$ & 4 & $4 * 10^{7} / 0.1$ & $40 * 10^{7}$ \\
\hline 8 & 0.1 & $10^{-1}$ & $10^{-8}$ & 2 & $2 * 10^{8} / 0.1$ & $20 * 10^{8}$ \\
\hline 9 & 0.1 & $10^{-1}$ & $10^{-9}$ & $\mathbf{0}$ & $0 * 10^{9} / 0.1$ & $0 * 10^{9}$ \\
\hline
\end{tabular}


Table.6 Chloroform and Saline Sensitivity of Phage

\begin{tabular}{|c|c|c|c|c|}
\hline \multirow[t]{2}{*}{$\begin{array}{l}\text { Time } \\
\text { (min.) }\end{array}$} & \multirow[t]{2}{*}{$\begin{array}{l}\text { Volume of Phage } \\
\text { Plated (ml) }\end{array}$} & \multirow[t]{2}{*}{$\begin{array}{l}\text { Dilution factor } \\
\text { (DF) }\end{array}$} & \multicolumn{2}{|c|}{$\begin{array}{c}\text { Titer : Plaque forming } \\
\text { unit (PFU) }\end{array}$} \\
\hline & & & Chloroform & Saline \\
\hline 5 & 0.1 & $10^{2}$ & $\mathbf{0}$ & $3.0 * 10^{-4}$ \\
\hline 10 & 0.1 & $10^{2}$ & $\mathbf{0}$ & $4.2 * 10^{-4}$ \\
\hline 15 & 0.1 & $10^{2}$ & $\mathbf{0}$ & $5.6 * 10^{-4}$ \\
\hline 20 & 0.1 & $10^{2}$ & $\mathbf{0}$ & $6.0 * 10^{-4}$ \\
\hline 25 & 0.1 & $10^{2}$ & $\mathbf{0}$ & $6.7 * 10^{-4}$ \\
\hline 30 & 0.1 & $10^{2}$ & $\mathbf{0}$ & $8.2 * 10^{-4}$ \\
\hline 35 & 0.1 & $10^{2}$ & $\mathbf{0}$ & $8.0 * 10^{-4}$ \\
\hline 40 & 0.1 & $10^{2}$ & $\mathbf{0}$ & $8.4 * 10^{-4}$ \\
\hline $\mathrm{P} \leq \mathbf{0 . 0 5}$ & & & & \\
\hline
\end{tabular}

Table.7 Phage Titer in Relation to Temperature $\left(37 \mathrm{C}^{\circ}, 50 \mathrm{C}^{\circ}\right.$ and $\left.65 \mathrm{C}^{\circ}\right)$

\begin{tabular}{|c|c|c|c|c|c|}
\hline \multirow[t]{2}{*}{ Time (min.) } & \multirow{2}{*}{$\begin{array}{c}\text { Volume of } \\
\text { phage } \\
\text { plated }(\mathrm{ml})\end{array}$} & \multirow[t]{2}{*}{ DF } & \multicolumn{3}{|c|}{ Titer : PFU } \\
\hline & & & $37 \mathrm{C}^{\circ}$ & $50 \mathrm{C}^{\circ}$ & $65 \mathrm{C}^{\circ}$ \\
\hline $\mathbf{1 0}$ & 0.1 & $10^{2}$ & $2.3 * 10^{-4}$ & $5.4 * 10^{-4}$ & $3.2 * 10^{-4}$ \\
\hline 20 & 0.1 & $10^{2}$ & $3.0 * 10^{-4}$ & $3.2 * 10^{-4}$ & $2.0 * 10^{-4}$ \\
\hline 30 & 0.1 & $10^{2}$ & $5.6 * 10^{-4}$ & $2.0 * 10^{-4}$ & $\mathbf{0}$ \\
\hline 40 & 0.1 & $10^{2}$ & $5.4 * 10^{-4}$ & $1.3 * 10^{-4}$ & $\mathbf{0}$ \\
\hline 50 & 0.1 & $10^{2}$ & $7.3^{*} 10^{-4}$ & $1.2 * 10^{-4}$ & $\mathbf{0}$ \\
\hline 60 & 0.1 & $10^{2}$ & $8.9 * 10^{-4}$ & $1.0 * 10^{-4}$ & $\mathbf{0}$ \\
\hline \multicolumn{3}{|c|}{ Means } & $5.41 * 10^{-4}$ & $2.35 * 10^{-4}$ & $0.86 * 10^{-4}$ \\
\hline \multicolumn{3}{|c|}{ Std.Deviation } & $1.39 * 10^{-4}$ & $1.69 * 10^{-4}$ & $1.06 * 10^{-4}$ \\
\hline \multicolumn{3}{|c|}{ Minimum } & $2.3 * 10-4$ & $1.0 * 10^{-4}$ & 0 \\
\hline \multicolumn{3}{|c|}{ Maximum } & $8.9 * 10-4$ & $5.4 * 10^{-4}$ & $3.2 * 10^{-4}$ \\
\hline
\end{tabular}

Figure.1 Photograph of the IC for Rotavirus
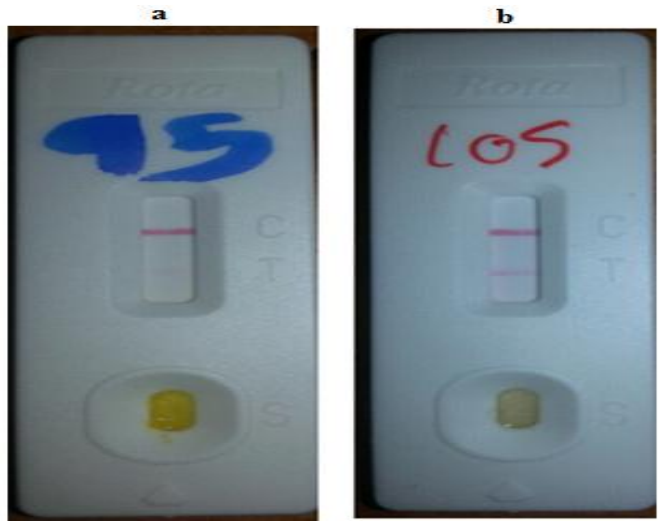

(a) Negative sample; (b) positive sample 
Figure.2 Polyacrylamide Gel Electrophoresis of dsRNA Rotavirus

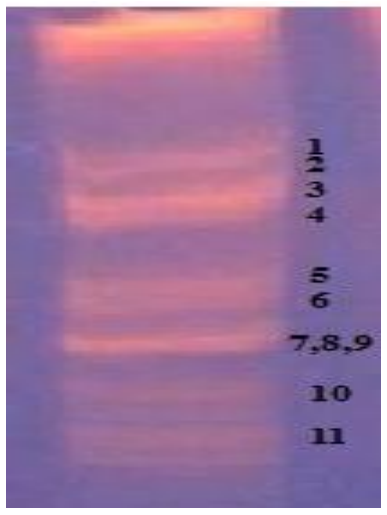

Figure.3 Rotavirus Particles Stained with Negative Staining under EM
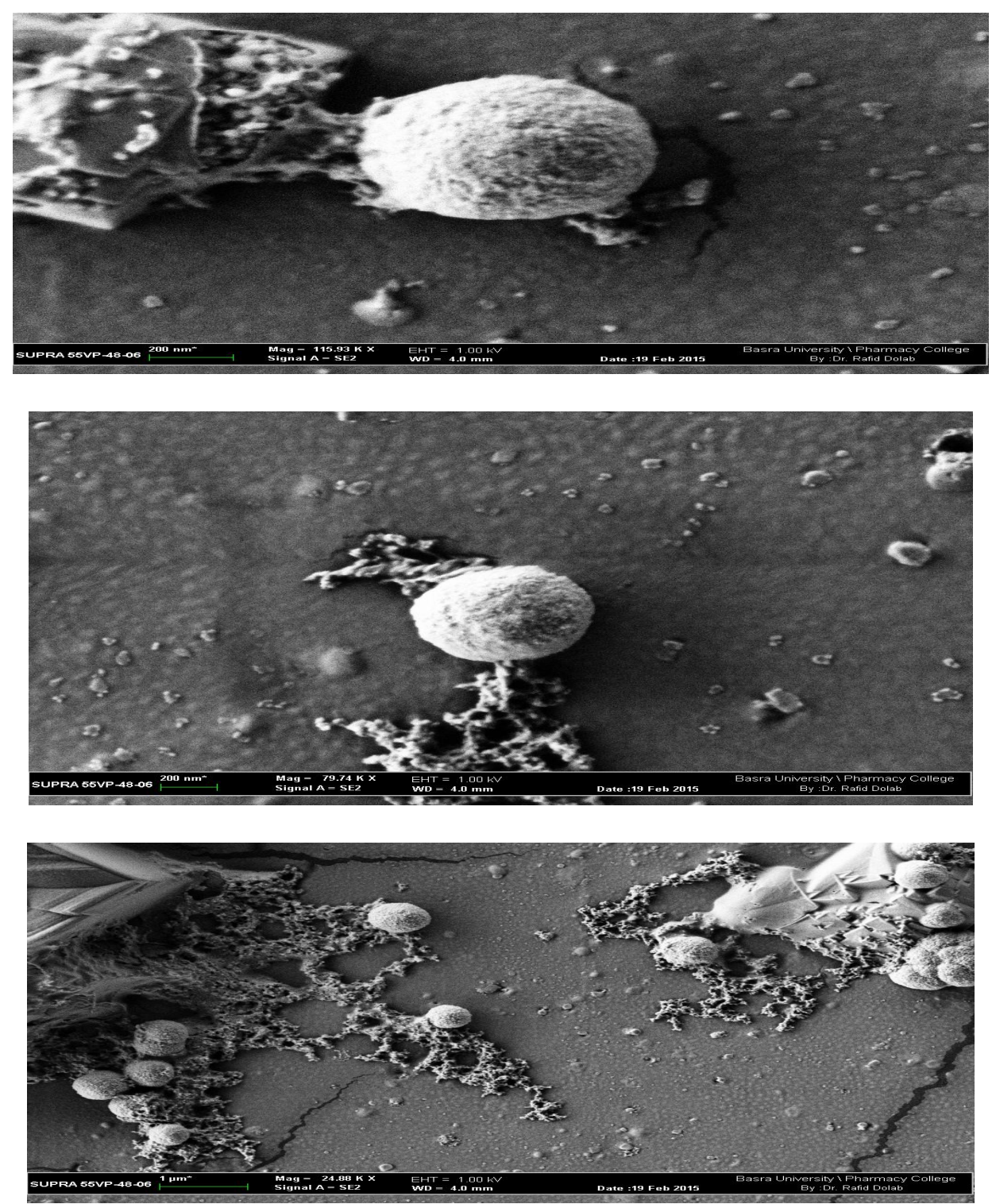


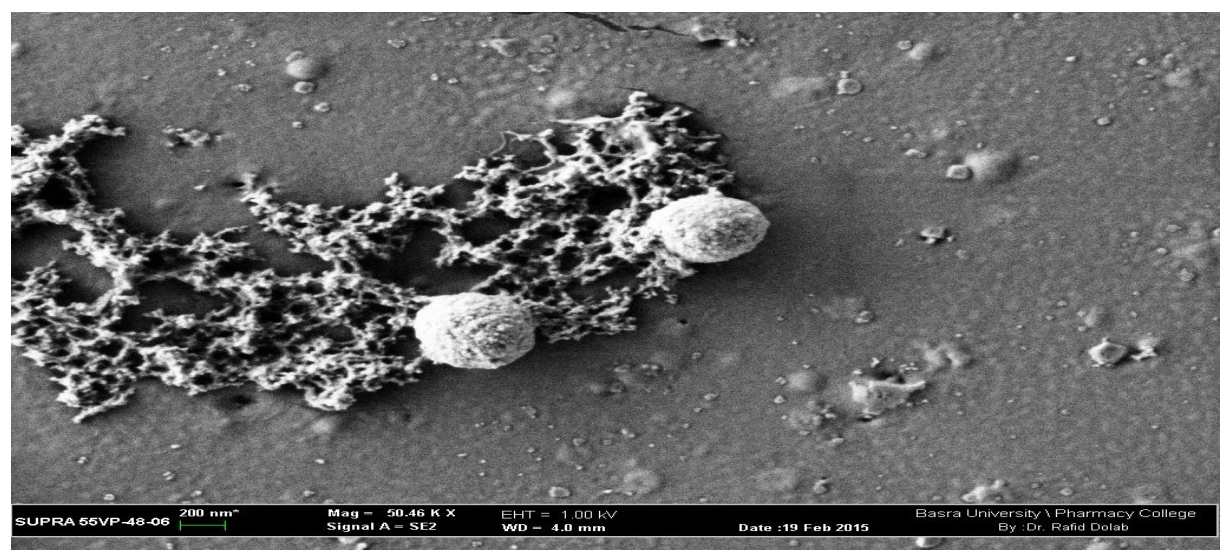

Figure.4 Api 20 Enterobacteraceae System for E. coli

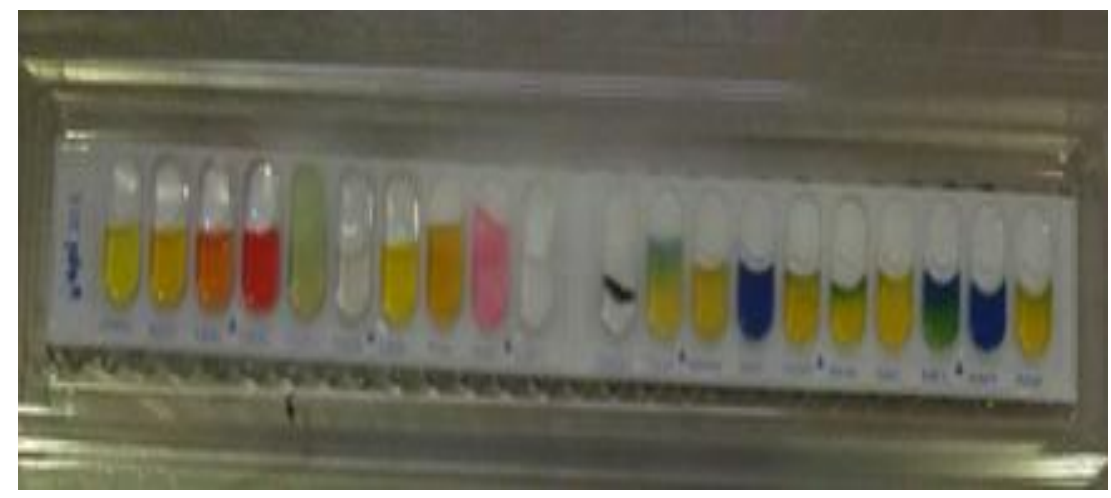

Figure.5 Spot Test of Phage

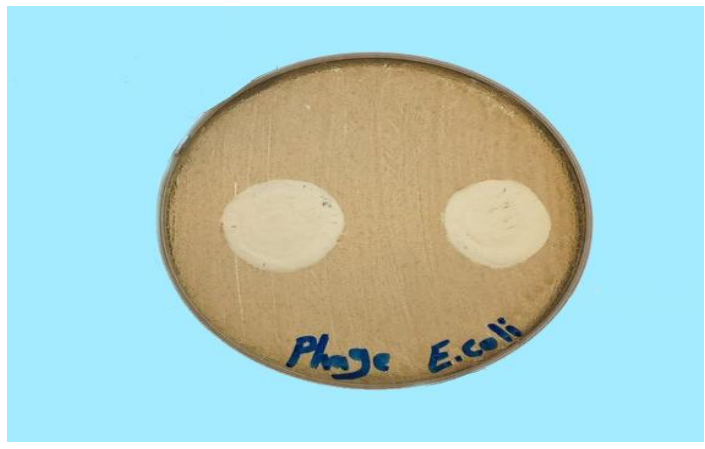


Figure.6 Plaques caused by Bacteriophage $\phi E C-M H 1$

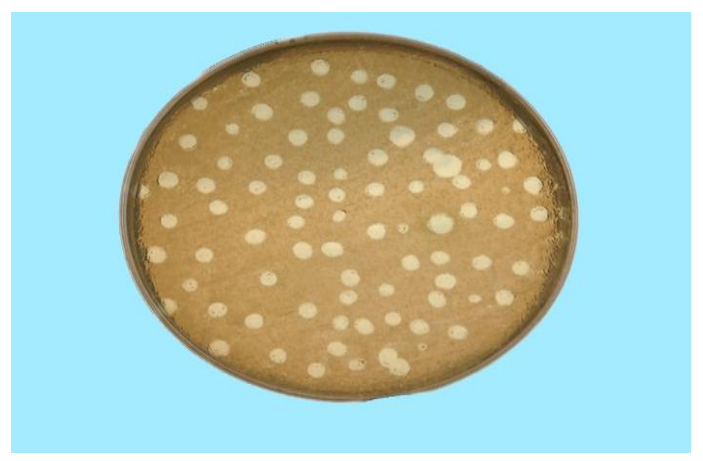

\section{Detection rates of Infectious Agents}

As shown in Table 3, in monoinfection 182(60.66\%) cases, viral agents (rotaviruses) were detected in 5/300 (1.66\%) samples, while the bacterial pathogens were found in $171 / 300$ (57\%) samples, also parasitic causes were found in $6 / 300(2 \%)$ samples, in addition, coinfections and mixing infections were detected in $118 / 300(39.34 \%)$ samples, with highly significant differences $(\mathrm{P}<0.001)$. Out of 93/300 (31\%) children had infections with Rotavirus, 5 (1.66\%) cases had monoinfection, $79(26.34 \%)$ coinfection, and 9(3\%) mixing infections. Regarding bacterial pathogens, 277/300 (92.33\%) children had infections with EPEC Escherichia coli: 163 (54.33\%), 105(35\%) and $9(3 \%)$ children had monoinfections, coinfection and mixing infections, respectively. Furthermore, among 39/300 (13\%) cases with Salmonella spp., 6(2\%) cases had monoinfection, 25(8.34\%) cases had coinfection and $8(2.66 \%)$ cases had mixing infection. While, Shigella spp. was reported in $12 / 300(4.01 \%)$ samples, $2(0.67 \%), 9(3 \%)$ and $1(0.34 \%)$ children had monoinfections, coinfection and mixing infections, respectively. Furthermore, in parasitic pathogens, Entamoeba histolytica and Giardia lamblia were found in 3/300 (1\%) samples as monoinfection cases (Table, 3).
Morbidity and mortality rates caused by diarrhea in developing countries remain high despite efforts to improve sanitary conditions, water quality, and the healthcare infrastructure (Sánchez-Fauquier et al., 2006). Rotavirus is ubiquitously distributed to humans and animals. Rotavirus has been recognized as a cause of infantile diarrhea since 1970s, and is now established as the most common cause of gastroenteritis in infants and young children (Kobayashi et al., 2007). After entrance orally into gastrointestinal tract, propagation of rotavirus occurs in epithelial cells of villi of small intestine. Cell lysis occurs finally by the viral propagation, causing curtailment of the villi. Diarrhea due to rotavirus infection is considered to be caused by some different mechanisms (Ramig, 2004). Transmitted by the fecal-oral route, rotavirus infects cells that line the small intestine producing an enterotoxin (NSP4) that induces gastroenteritis (Diggle, 2007). Although good hygiene measures can help prevent spread of the disease, the robustness of rotavirus and the low infectious dose (10100 virus particles), makes standard sanitary measures to halt transmission of the virus relatively ineffective (Gray, 2011). The extended programme on immunization was initiated in Iraq in 2012. Rotavirus vaccine was introduced as a result of the increasing mortality and morbidity associated with acute gastroenteritis. All 3 doses of vaccine 
are required for maximum protection (Vesikari et al., 2006). In addition, although there has been a downward trend in the number of cases of gastroenteritis caused by bacteria and parasites in young children over the last ten years, the proportion of gastroenteritis cases due to viruses, and to rotavirus in particular, has remained stable (Iturriza-Gomara et al., 2008). In our study, coinfection with another pathogen was observed in 109/300 (36.34\%) cases (Table, 3), coinfection with Rotavirus and EPEC Escherichia coli were the most common and occurred in 75/300 (25\%). Overall, 93/300(31\%) showed positive results for rotavirus. These results were lower than previous findings on rotavirus prevalence $(51.98 \%)$ in Najaf governorate (Al-Kelaby, 2008). Al-Ameen et al., 2012 study showed the positive cases of rotavirus to total samples of diarrhea were $278(39.66 \%)$ in Basra Province/Iraq from 2008-2011. Also Thwiny, 2013 showed that group A rotavirus, sapovirus, norovirus, astrovirus and adenovirus were detected in $40.5 \%$, $21.5 \%, 8 \%, 2.5 \%$ and $2.5 \%$ of the study population in Basra Province/Iraq, respectively.

Furthermore, this was lower than the prevalence of rotavirus attained in Syria (61\%) (Teleb, 2008), Oman (50\%) (AlAwaidy et al., 2009) and Kuwait (44\%) (Marmash et al., 2007). Otherwise, Lee et al., 2007 studied the etiologic agents in 962 Korean children hospitalized with gastroenteritis that rotavirus, norovirus, adenovirus and astrovirus were detected in $25.7 \%, 13.7 \%, 3.0 \%$, and $1.1 \%$ of the study population, respectively. These different detection rates may be explained by different conditions of the studies, such as the season of sampling and the sampling methods, also because rotaviral infection rates can vary both over time and geographically within the same country.

\section{Bacterial Pathogens Isolation and Antimicrobial Susceptibility Test}

The bacterial pathogens were isolated from 289(96.34\%) children with acute diarrhea including: EPEC Escherichia coli, Salmonella spp. and Shigella spp. according to routine bacteriological and biochemical assays that were later confirmed by api 20 Enterobacteraceae system (Figure, 4). Antibiotic susceptibility testing was performed on Muller Hinton agar against five different antibiotics to 30 isolates of EPEC Escherichia coli. The antibiotic resistance/susceptibility profile of EPEC E.coli isolates revealed that most of the isolates were resistant to three tested antibiotics (Table, 4).

\section{Coliphage Characterization}

The phage was isolation successfully from sewage. The host range of phage was determined against four isolates of EPEC $E$. coli; the phage was showed lytic activity against all isolates (Figure, 5). The phage was named $\phi E C-\mathrm{MH} 1$, and then it was selected for further experiments. Number of p.f.u. for each dilution $\left(10^{-1}, 10^{-2}, 10^{-3}, 10^{-4}\right.$, $\left.10^{-5}, 10^{-6}, 10^{-7}, 10^{-8}, 10^{-9}\right)$, was $800^{*} 10^{1}$, $850 * 10^{2}, \quad 760 * 10^{3}, \quad 560 * 10^{4}, \quad 320 * 10^{5}$, $270^{*} 10^{6}, \quad 40 * 10^{7}, \quad 20 * 10^{8}, \quad 0 * 10^{9}$, respectively(Table, 5; Figure, 6). This result revealed that dilution factor $10^{-2}$ was the best countable number of plaques. Table (6) showed Chloroform and saline sensitivity of phage. Chloroform sensitivity on number of plaques and phage titer during different time was 0 , which revealed to complete inactivated of phage. Sensitivity of phage titer to saline environments (Min. - Max.; mean \pm standard deviation: $3.0^{*} 10^{-4}$ $8.4^{*} 10^{-4} ; 6.26^{*} 10^{-4} \pm 1.96^{*} 10^{-4}$ ) was $3.0 * 10^{-4}$,

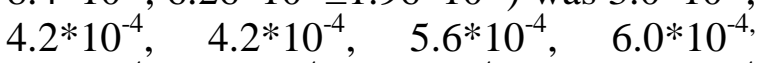
$6.7 * 10^{-4}, 8.2 * 10^{-4}, 8.0^{*} 10^{-4}$, and $8.4 * 10^{-4}$ during $5,10,15,20,25,30,35$ and 40 
minutes respectively. Also by using different time 10, 20,30,40,50, and 60 minutes and different temperature $37 \mathrm{C}^{\circ}$ (as control group), $50 \mathrm{C}^{\circ}$ and $65 \mathrm{C}^{\circ}$, temperature sensitivity effect on phage titer was $2.3 * 10^{-4}$, $3.0^{*} 10^{-4}, \quad 5.6 * 10^{-4}, \quad 5.4 * 10^{-4}, \quad 7.3 * 10^{-4}$, $8.9 * 10^{-4}$ and $5.4 * 10^{-4}, 3.2 * 10^{-4}, 2.0^{*} 10^{-4}$, $1.3^{*} 10^{-4}, 1.2^{*} 10^{-4}, 1.0^{*} 10^{-4}$ and $3.2 * 10^{-4}$, $2.0^{*} 10^{-4}, 0,0,0,0$, respectively (Table, 7 ).

Bacteriophages have very effective bactericidal activity and several advantages over other antimicrobial agents. Most notably, phages replicate at the expense of infectious bacteria, are available in abundance where they are most required, and so far, no serious or irreversible side effects of phage therapy have been described (Sulakvelidze and Kutter, 2005). If bacteria become resistant to phages then phages do evolve naturally to infect the aforementioned resistant bacteria, hence minimizing the chances of bacterial escape, which scores another advantage of phage over antibiotics (Hausler, 2007). At the moment it seems a bit far that phage therapy will replace antibiotics exclusively, but there is the hope that it will be used complementary to antibiotics especially for antibiotic resistant strains (Clark and March, 2006).

In conclusion, this study added several data to the knowledge on the epidemiology of main diarrheagenic pathotypes infections in one of the country's regions. In our study the use of different tests would allow monitoring of the diversity of circulating rotavirus strains. We found that rotaviruses easy detected because the viruses shedding in large quantities and has a circular shape size of $65-70 \mathrm{~nm}$ ranges. Rotavirus A could be diagnosed in stool samples of children with gastroenteritis by IC test as a rapid technique. Negative staining EM was a valuable technique to monitor the presence rotaviruses infection. Rotavirus and EPEC Escherichia coli were the most common coinfectious agents responsible for gastroenteritis. Children between an age of 0 and 11 months were at greatest risk for developing severe disease from diarrheagenic pathotypes infection. The phage was showed lytic activity against all EPEC Escherichia coli isolates.

\section{References}

Al-Ameen, H.A., Al-Hmudi, H.A., Darush, A. 2012. Epidemiology of Rotavirus Cases among Children under Age 5 Years in Basra Province from 20082011. J. Thi-Qar Sci., Vol. 3(3): 3136.

Al-Awaidy, S.A., Bawikar, S., Al Busaidy, S, et al. 2009. Considerations for introduction of a rotavirus vaccine in Oman: rotavirus disease and economic burden. J. Infect. Dis., 200(Suppl 1): 248-253.

Al-Kelaby, K.K.A. 2008. Study on rotavirus serovars G1 and G2 isolated from acute diarrhea of children; Ph.d thesis, Babylon University.

Armah, G.E., Steele, A.D., Binka, F.N., et al. 2003. Changing Patterns of Rotavirus Genotypes in Ghana: Emergence of Human Rotavirus G9 as a Major Cause of Diarrhea in Children. J. Clin. Microbiol., 41: 2317-2322.

Atmar, R.L., Estes, M.K. 2001. Diagnosis of noncultivatable gastroenteritis viruses, the human caliciviruses. Clin. Microbiol. Rev., 14: 15-37.

Bauer, A.W., Kirby, W.M., Sherris, J.C., Turch, A. 1966. Antibioic susceptibility testing by standardized single disk method. W. M. Ameri. J. Clin. Pathol., 45: 493.

Beards, G.M. 1988. Laboratory diagnosis of viral gastroenteritis. Eur. J. Clin. 
Microbiol. Infect. Dis., 7: 11-13.

Berg, H.C. 2004. E. coliin Motion. Biolog. Med. Phys. Biomed. Eng.

Broor, S., Singh, V. 1984. Viral gastroenteritis. Indian J. Gastroenterol., 3: 225-229.

Bishop, R.F., Davidson, G.P., Holmes, I.H. 1974. Detection of a new virus by electron microscopy of faecal extracts from children with acute gastroenteritis. Lancet, 149-151.

Bon, F., Kaplon, J., Metzger, M.H., Pothier, P. 2007. Evaluation of seven immunochromatographic assays for the rapid detection of human rotaviruses in fecal specimens. Pathol. Biol., 55: 149-153.

Clark, J.R., March, J.B. 2006. Bacteriophages and biotechnology: vaccines, gene therapy and antibacterials. Trends Biotechnol., 24(5): 212-218.

Collee, J.G., Franser, A.G., Marmion, B.P., Simmons, A.S. 1996. Practical medical microbiology. $14^{\text {th }}$-ed Churchill living stone, New York.

Curry, A., Appleton, H., Dowsett, B. 2006. Application of transmission electron microscopy to the clinical study of viral and bacterial infections: present and future. Micron, 37: 91-106.

Diggle, L. 2007. Rotavirus diarrhea and future prospects for prevention. $B r$. J. Nurs., 16(16): 970-974.

Forbes, B.A., Sahman, D.F., Weissfeld, A.S. 1998. Bailey and Sctt s diagnostic microbiology. $10^{\text {th }}$-ed. Mosby, Company, USA.

Fujimoto, T., Okafuji, T., Okafuji, T. et al. 2004. Evaluation of a Bedside Immunochromatographic Test for Detectionof Adenovirus in Respiratory Samples, by Comparison to VirusIsolation, PCR, and RealTime PCR. J. Clin. Microbiol., 5489-5492.
Gleizes, O., Desselberger, U., Tatochenko, V. et al. 2006. Nosocomial rotavirus infection in European countries: a review of the epidemiology, severity and economic burden of hospitalacquired rotavirus disease. Pediatr. Infect. Dis. J., 25(1 Suppl): 12-21.

Gomes, T.A.T., Rassi, V., MacDonald, K.L. et al. 1991. Enteropathogens associated with acute diarrheal disease in urban infants in $\mathrm{Sa}^{\sim} \mathrm{O}$ Paulo, Brazil. J. Infect. Dis., 164: 331-337.

Gray, J. 2011. Rotavirus vaccines: safety, efficacy and public health impact. $J$. Int. Med., 270: 206-214.

Gupta, S. 1995. Short text book of medical microbiology. $6^{\text {th }}$-ed. Brothers Medical Publishers (P) LTD, India.

Hara, M., Sadamatsu, K., Takao, S. et al. 2006. Evaluation of IC test for rapid detection of influenza $A$ and $B$ viruses using real-time PCR. Kansenshogaku Zasshi, 80: 522-526.

Hara, M. 2002. Usefulness of immunochromatography

"Adenocheck ${ }^{\circledR}$ " for rapid diagnosis of adenoviral respiratory tract infection in childhood, J. Jpn. Pediatr. Soc., 106: 42-45.

Hausler, T. 2007. Viruses vs. Superbugs: A Solution to the Antibiotics Crisis, London: Macmillan.

Herring, A.J., Inglis, N.F., Ojeh, C.K. et al. 1982. Rapid diagnosis of rotavirus infection by direct detection of viral nucleic acid in silverstained polyacrylamide gels. J. Clin. Microbiol., 16: 473-477.

Inal, J.M. 2003. Phage therapy: a reappraisal of bacteriophages as antibiotics. Arch. Immunol. Ther. Exp., 51(4): 237-244.

Iturriza-Gomara, M., Elliot, A.J., Dockery, C. et al. 2008. Structured surveillance of infectious intestinal 
disease in pre-school children in the community: 'The Nappy Study'. Epidemiol. Infect., 1-10.

Kageyama, T.S., Kojima, S., Shinohara, M. et al. 2003. Broadly reactive and highly sensitive assay for Norwalk -like viruses based on real-time quantitative reverse transcriptionPCR. J. Clin. Microbiol., 41: 15481557.

Kapikian, A.Z., Hoshino, Y., Chaock, R.M. 2001. Rotaviruses. In: Knipe, D.M., Howley, P.M., Griffin, D.E. et al., ed. Fields Virology. Philadelphia, Lippincott Williams \& Wilkins: 1787-1833.

Kobayashi, N., Ishino, M., Wang, Y.H. et al. 2007. Diversity of G-type and P-type of human and animal rotaviruses and its genetic background, Communicating Curr. Res. Edu. Topics and Trends in Appl. Microbiol., 847-858.

Lee, J.I., Chung, J.Y., Han, T.H., et al. 2007. Detection of human bocavirus in children hospitalized because of acute gastroenteritis. J. Infect. Dis., 196: 994-997.

Liu, L.J., Liu, W., Liu, Y.X., et al. 2010. Identification of norovirus as the top enteric viruses detected in adult cases with acute gastroenteritis. Am. J. Trop. Med. Hyg., 82(4): 717-722.

Mangia, A.H., Duarte, N.A., Duarte, R. et al. 1993. A etiology of acute diarrhea in hospitalized children in Rio de Janeiro city, Brazil. J. Trop. Pediatr., 39: 365-367.

Marmash, R.W., Dalwai, A.K., Szucs, G., et al. 2007. Genotypic characterization of rotaviruses and prevalence of serotype-specific serum antibodies in children in Kuwait. Epidemiol. Infect., 135(8): 1331-1337.

Parashar, U.D., Bresee, J.S., Gentsch, J.R., Glass, R.I. 1998. Rotavirus. Emerg.
Infect. Dis., 4: 561-70.

Parashar, U.D., Hummelman, E.G., Bresee, J.S., et al. 2003. Global illness and deaths caused by rotavirus disease in children. Emerg. Infect. Dis., 9: 565572.

Parashar, U.D., Gibson, C.J., Bresse, J.S., Glass, R.I. 2006. Rotavirus and severe childhood diarrhea. Emerg. Infect. Dis., 12(2): 304-306.

Parkin, P.C., Macarthur, C., Khambalia, A., et al. 2009. Clinical and laboratory assessment of dehydration severity in children with acute gastroenteritis. Clin. Pediatr., 49: 235-239.

Ramig, R.F. 2004. J. Virol., 78: 10213.

Rheingans, R.D., Heylen, J., Giaquinto, C. 2006. Economics of rotavirus gastroenteritis and vaccination in Europe: what makes sense. Pediatr. Infect. Dis. J., 25: 48-55.

Sambrook, J., Russell, D.W. 2001. Molecular cloning: a laboratory manual., $3^{\text {rd }}$ ed.; Cold Spring Harbor Laboratory Press: NY.

Sánchez-Fauquier, A., Montero, V., Moreno, S., et al. 2006. Human rotavirus $\mathrm{G} 9$ and $\mathrm{G} 3$ as major cause of diarrhea in hospitalized children, Spain. Emerg. Infect. Dis., 12(10): 1536-1541.

Sauer, T.J., Daniel, T.C., Nichols, D.J., West, C.P., et al. 2000. Runoff water quality from poultry litter -treated pasture and forest sites. J. Environ. Qual., 29: 515.

Sulakvelidze, A., Kutter, E. 2005. Bacteriophage therapy in humans. In Bacteriophages: Biology and Application. Kutter E, Sulakvelidze A., editors: 381-436. Boca Raton, CRC Press.

Surendran, S. 2008. Rotavirus Infection: Molecular changes and pathophysiology. Excli. J., 7: 154- 
162

Teleb, N. 2008. Rotavirus Surveillance Network in the Eastern Mediterranean regional. Presented at the 8th International Rotavirus Symposium, June 3-4 Istanbul.

Thwiny, H.T. 2013. Molecular detection and epidemiology of five enteric viruses (Rotavirus A, Norovirus, Sapovirus, Astrovirus and Adenovirus) among children with acute diarrhea in Basrah. Iraq. Ph.d thesis, Basrah
University.

Tsutsumi, H., Ouchi, K., Ohsaki, M. et al. 1999. Immunochromatography test for rapid diagnosis of adenovirus tract infections: comparison with virus isolation in tissue culture. $J$. Clin. Microbiol., 37: 2007-2009.

Vesikari, T., Matson, D.O., Dennehy, P. et al. 2006. Safety and efficacy of a pentavalent human-bovine (WC3) reassortant rotavirus vaccine. $N$. Engl. J. Med., 354: 23-33.

\section{How to cite this article:}

Marwa M. Yaqoob, Kuther H. Mahdi, Hayder Abdulhussein Al-Hmudi and Mariem N. Mohammed-Ali. 2016. Detection of Rotavirus A and Escherichia coli from Diarrhea Cases in Children and Coliphage Characterization. Int.J.Curr.Microbiol.App.Sci. 5(4): 68-83. doi: http://dx.doi.org/10.20546/ijcmas.2016.504.011 